Marek Derenowski

Uniwersytet im. Adama Mickiewicza, Kalisz

\title{
JOLANTA KNIEJA, TOMASZ ZYGMUNT, ŁUKASZA BRZANA (RED.) LITERATUROZNAWSTWO, JĘZYKOZNAWSTWO I KULTUROZNAWSTWO JAKO PŁASZCZYZNY PRZEKAZU WE WSPÓŁCZESNEJ GLOTTODYDAKTYCE WYDAWNICTWO WERSET, LUBLIN 2010, 518 sS. Omówienie publikacji
}

Pozycja Literaturoznawstwo, językoznawstwo i kulturoznawstwo jako płaszczyzny przekazu we współczesnej glottodydaktyce to - między innymi - efekt spotkania szerokiego gremium specjalistów teoretyków i praktyków, jakie w maju 2010 zorganizował Instytut Neofilologii Państwowej Wyższej Szkoły Zawodowej w Chełmie. Klamrą spinającą wszystkie części omawianej publikacji są rozważania nad celami nauczania języka w szeroko rozumianej perspektywie społecznej. Tematyka mogło by się wydawać nie najnowsza, gdyż już w latach siedemdziesiątych ubiegłego wieku rozpoczęto rozważania nad procesem glottodydaktycznym, w którym to uczeń znajdowałby się w centrum uwagi, jednakże tak samo jak wcześniejszy model oparty na nauczycielu, tak i ten oparty na uczniu nie był wolny od niedoskonałości i podlegał nieustannym modyfikacjom wynikającym ze zmian zachodzących zarówno w środowisku ucznia jak i nauczyciela (metody nauczania, pomoce dydaktyczne, materiały do nauki języka, formy przekazu). Nie bez znaczenia były też zmiany zachodzące $w$ samych uczestnikach procesu glottodydaktycznego (motywacja, oczekiwania, nastawienie, itp.).

Bezdyskusyjnym pozostaje natomiast dziś stwierdzenie, że sama kompetencja lingwistyczna nie wystarczy do efektywnego nauczania języka. Współczesny nauczyciel oprócz przygotowania językowego musi posiadać 
wiedzę z zakresu socjolingwistyki i psycholingwistyki. W procesie kształcenia przyszłych nauczycieli należy zaś zwrócić szczególną uwagę na dynamicznie zmieniający się kontekst kulturowy i społeczny. W świecie postrzeganym jako „globalna wioska”, podróże są łatwiejsze, a kontakty między przedstawicielami rożnych kultur stały się czymś naturalnym. Tym samym niezbędne jest wykształcenie w nauczycielach i uczniach kompetencji interkulturowej, która pozwoli na bardziej efektywną wymianę emocji, myśli i poglądów stanowiących podstawę komunikacji międzyludzkiej. Dlatego też zamysł przygotowania publikacji o charakterze teoretyczno-praktycznym, zawierającej prace z zakresu językoznawstwa, literaturoznawstwa, kulturoznawstwa i glottodydaktyki, autorstwa wielu znanych specjalistów afiliowanych w polskich i zagranicznych ośrodkach akademickich, jest przedsięwzięciem bardzo cennym.

Omawiany tom składa się z ośmiu części.

Część pierwsza: Rozważania językoznawcze (str. 15-119), w dwunastu artykułach (osiem w języku polskim, cztery w języku rosyjskim) porusza zarówno zagadnienia teoretyczne jak i rozważania praktyczne wynikające ze związków językoznawstwa z innymi dziedzinami nauki.

W drugiej części: Tekst jako płaszczyzna rozwiqzań glottodydaktycznych (str. 123-156), czytelnik znajdzie cztery opracowania w języku polskim, poświęcone szeroko zdefiniowanej analizie tekstu w ścisłym odniesieniu do procesu dydaktycznego.

Trzecia część: Miejsce przekładu w procesie glottodydaktycznym (str. 159-188), zawiera cztery teksty, w których Autorzy wskazują na konkretne przykłady zastosowania i użyteczności przekładu w procesie glottodydaktycznym, także w odniesieniu do tekstu literackiego.

Glottodydaktyka w szkole wyższej (str. 191-282), to tytuł czwartej części tomu zawierającej aż dziesięć artykułów, w których Autorzy łączą teoretyczne zagadnienia językoznawcze, literaturoznawcze i kulturoznawcze z codzienną praktyką akademicką.

Na część piątą - Rozważania literaturoznawcze (str. 285-318) - składają się cztery teksty polskojęzyczne oraz cztery teksty w języku rosyjskim - wszystkie prezentują wybrane zagadnienia z zakresu analizy tekstu literackiego.

Efektywne rozwijanie kompetencji interkulturowej w procesie glottodydaktycznym to motyw przewodni prac zamieszczonych w rozdziale szóstym: Rozważania kulturoznawcze (str. 321-381). Tematyka w nim poruszana dotyczy sposobów integrowania tzw. informacji kulturowej z procesem nauczania/uczenia się języka obcego.

Część siódma: Rola języka ojczystego na lekcji języka obcego (str. 385418), skupia uwagę czytelnika na zagadnieniu wykorzystaniu języka ojczystego podczas zajęć języka obcego. Bardzo często, szczególnie nauczyciele z małym 
stażem zawodowym, postrzegają język ojczysty jako niepożądany podczas zajęć językowych. Prezentowane teksty wskazują dobitnie, że język ojczysty może być bardzo przydatnym narzędziem w nauczaniu języka obcego.

Ostatnia, ósma część: Praktyczne zastosowania (str. 421-518), zawiera wybór artykułów (dziesięć tekstów) prezentujących szeroki zestaw praktycznych rozwiązań stosowanych w pracy glottodydaktycznej. Teksty te zawierają cenne wskazówki na temat kształtowania kompetencji językowej, komunikacyjnej i kulturowej u uczących się języków obcych i mogą być także inspiracją do dalszych działań dydaktycznych.

Literaturoznawstwo, językoznawstwo i kulturoznawstwo... - teksty zebrane przez Jolantę Knieję, Tomasza Zygmunta i Łukasza Brzanę - jest więc publikacją wartościową z kilku względów. Po pierwsze, jest to publikacja skupiająca w jednym tomie szerokie grono ekspertów z różnych pokrewnych dziedzin, co pozwala na zaprezentowanie różnorakich opinii, wielu punktów widzenia i wielorakich koncepcji pracy dydaktycznej. Po drugie, publikacja ma szeroki wymiar zarówno praktyczny jak i teoretyczny. Może stanowić inspirację dla nauczycieli, którzy znajdą tu szeroki wachlarz praktycznych pomysłów do wykorzystaniach na lekcjach języka obcego, jak i dla badaczy jako przyczynek do dalszych rozważań i obserwacji. Po trzecie, tom pomimo dużej ilości zawartych w nim artykułów (również obcojęzycznych) jest spójny, a jego kompozycja - przejrzysta.

Cały tom rekomenduję gorąco zarówno badaczom z kręgu glottodydaktyki, jak i nauczycielom języków obcych oraz studentom - adeptom zawodu nauczyciela. 